\title{
Morphology, density and dimensions of bamboo fibers: a bibliographical compilation ${ }^{1}$
}

\author{
Fernando Rusch ${ }^{2}$, Guilherme Bordignon Ceolin ${ }^{3}$, Éverton Hillig ${ }^{2}$
}

\section{ABSTRACT}

Bamboos are fast-growing plants, with outstanding physical-mechanical characteristics that may be chiefly ascribed to the features and dimensions of their main structural element: their fibers. This study aimed to perform a dimensional description (length, width, lumen diameter and wall thickness) and depict the indices and technical coefficients of fibers of bamboo species that occur in Brazil, through a bibliographical survey. The results showed that the basic density in test stemspecimens of the surveyed species varied between $0.451 \mathrm{~g} \mathrm{~cm}^{-3}$ and $0.780 \mathrm{~g} \mathrm{~cm}^{-3}$, what revealed a great variability among them. The average values observed for the fiber dimensions were $2.29 \mathrm{~mm}$ for length, $16.4 \mu \mathrm{m}$ for total width, $6.4 \mu \mathrm{m}$ for wall thickness and $3.5 \mu \mathrm{m}$ for lumen diameter. From these data, it was possible to estimate indices and technical coefficients that support good physical-mechanical characteristics of bamboo in the several studied species.

KEYWORDS: Fiber slenderness ratio, Runkel index, fiber flexibility coefficient, fiber wall fraction.

\section{INTRODUCTION}

Bamboo is a generalist name for specimens of the Bambusoideae subfamily (Poaceae) (Yeasmin et al. 2014). Despite this classification, many species are capable of reaching large heights and diameters. Thus, bamboos are considered an alternative source of wood to cope with the shortage in the availability of certain timber species, allowing the nature preservation. Because bamboos are fastgrowing monocotyledons, they are often classified as environmental regenerators, since their ability to quickly occupy degraded soils decreases erosive processes.

\section{RESUMO}

Morfologia, densidade e dimensões de fibras de bambu: uma compilação bibliográfica

Os bambus são plantas que apresentam rápido crescimento, com excelentes propriedades físico-mecânicas, as quais derivam, principalmente, das características e dimensões de seu principal elemento estrutural: suas fibras. Objetivou-se realizar a descrição dimensional (comprimento, largura, diâmetro do lume e espessura da parede) e caracterizar os índices e coeficientes técnicos das fibras de espécies de bambu que ocorrem no Brasil, por meio de levantamento bibliográfico. Os resultados mostraram que a densidade básica em corpos de prova de hastes das espécies levantadas variou entre $0,451 \mathrm{~g} \mathrm{~cm}^{-3}$ e $0,780 \mathrm{~g} \mathrm{~cm}^{-3}$, evidenciando grande variabilidade entre elas. Os valores médios observados para as dimensões das fibras foram 2,29 mm de comprimento, $16,4 \mu \mathrm{m}$ para largura total, $6,4 \mu \mathrm{m}$ de espessura da parede e 3,5 $\mu \mathrm{m}$ para o diâmetro do lume. A partir destes dados, foram estabelecidos índices e coeficientes técnicos que sustentam boas propriedades físico-mecânicas do bambu nas várias espécies estudadas.

PALAVRAS-CHAVE: Índice de enfeltramento, índice de Runkel, coeficiente de flexibilidade da fibra, fração de parede da fibra.

The main hypothesis for the origin of its popular name is the loud noise it supposedly makes when burned: "bam-boo" (Greco \& Cromberg 2011). Besides this denomination, bamboos are also popularly known in Brazil as "taboca" or "taquara", terms derived from indigenous languages.

Several bamboo species are spread worldwide, being southeast Asia the region with the greatest richness and tradition of use. However, Africa and South America are continents with considerable amount of both native and exotic species occupying a significant territorial area, although with small richness (Filgueiras \& Gonçalves 2004). Especially in Brazil, Filgueiras et al. (2013) found 267 species,

1. Received: Sep. 17, 2018. Accepted: Mar. 26, 2019. Published: Jul. 04, 2019. DOI: 10.1590/1983-40632019v4955007.

2. Universidade Estadual do Centro-Oeste, Departamento de Engenharia Florestal, Irati, PR, Brasil.

E-mail/ORCID: fe_rusch@yahoo.com.br/0000-0001-5221-835X, hillig@hotmail.com/0000-0002-7895-2453.

3. Universidade Federal de Santa Maria, Departamento de Engenharia Florestal, Frederico Westphalen, RS, Brasil.

E-mail/ORCID: ceolingb@gmail.com/0000-0003-1187-2528. 
from 45 genera (160 endemic). On the other hand, Greco et al. (2015) reported that 164 species in 17 genera are woody bamboos.

The use of bamboo by humankind is millenary (Pereira 2012), with a high potential for job creation and source of income in several countries that explore its proprieties. Bamboo species may be a good material for the wood industry, either being extracted from natural areas or from homogeneous plantations, despite the significant variation of productivity per unit area. For instance, Hernández-Mena et al. (2014) stated that bamboos can produce around $30 \mathrm{t} \mathrm{ha}^{-1}$ of biomass, while, for Lanna et al. (2014), their production ranges from $20 \mathrm{tha}^{-1}$ to $60 \mathrm{t} \mathrm{ha}^{-1}$. In turn, Dias Júnior et al. (2014) emphasize that, for some Bambusa species, the production fluctuates between $50 \mathrm{t} \mathrm{ha}^{-1}$ year- $^{-1}$ and $100 \mathrm{t} \mathrm{ha}^{-1}$ year ${ }^{-1}$, depending on the conditions of the place. These differences, rather than being deterrents to the industry, suggest that the industrialization of different species is feasible, depending on the goal to be reached.

Bamboos have been used for centuries in several countries, especially in Asia (China, India and Thailand), Central America (Costa Rica, Mexico and Honduras) and South America (Peru, Ecuador and Colombia) (Nepal 2011, Silveira et al. 2017). Some estimates indicate that bamboos may be used for at least three thousand purposes, including food (both human and animal feed), construction material and handicrafts, energy and industrial raw material in several products, such as ethanol (Kuttiraja et al. 2013), composites (Chaowana 2013), panels (Liu et al. 2016), textiles (Nayak \& Mishra 2016) and cellulose (Tripathi et al. 2018).

The species used are generally from Asia, both tropical and subtropical. This climatic range allows that bamboo species reach satisfactory growth rates when adapted to different soil and climate conditions in the Brazilian territory, especially the Bambusa genus (156 species), which originates in Asia, Oceania and Madagascar. Other genera are equally explored, such as Dendrocalamus (Asia and Oceania; 66 species), better known for its usually large-sized species. Another important genus is Guadua (33 species), occurring from Mexico to Uruguay, being particularly common in the Amazon region. Finally, it is possible to cite Ochlandra (10 species), originating in Asia, especially in India and Sri Lanka (Vorontsova et al. 2017).

Regarding morphological features, several aspects can be highlighted among the bamboo species occurring in Brazil: cell wall thickness, diameter, stem length and longitudinal linearity, together with a high productivity in biomass. Such characteristics demonstrate that there is a potential for their industrial use (Ostapiv 2011). The industrial potential of these species occurs not only because of their rapid growth, but also because they show physical-mechanical characteristics good enough to be explored in constructions, in their structural form, coatings and production of laminated floors and panels (Rusch et al. 2019).

Because of the variability in the anatomical characteristics, different productive activities require different species to be used. These differences regard particularly the dimensions of the fibers, their main structural element. To Guimarães Junior et al. (2010), the average values for the dimensions of bamboo fibers can be used to estimate others attributes, such as the felting index (relation between the fiber length and width), coefficient of flexibility (ratio of fiber diameter to fiber width), wall fraction (ratio of cell wall thickness to fiber width) and Runkel index (ratio of cell wall thickness to fiber lumen diameter). In order to appropriately calculate these indices, it is essential to map these anatomic properties, aiming to establish parameters for the use of this raw material. Thus, this study compiles from the literature such fiber properties of different bamboo species occurring in Brazil, in order to characterize the volume of available commercial material, basic densities, flexibility and resistance to the industrial processing.

\section{MICROMETRIC ANALYSIS OF BAMBOO FIBERS}

Fibers are cellulosic materials that occur naturally in the inner stem of bamboos and, in general, their dimensions are long and thin, although they have thick cell walls and reduced lumen diameters (Azzini \& Salgado 1982).

In order to determine the fiber size in several Brazilian bamboo species, a bibliographic survey was carried out based on a study developed during the 1970s and 1980s, as a partnership between the Instituto Agronômico de Campinas (São Paulo, Brazil) and the Brazilian National Bank for Economic Development, whose results were published in journals and scientific bulletins.

At the time of the study, specific samples of Bambusa (B. dissimulator, B. malingensis, B. nutans, 
B. oldhamii, B. stenostachya, B. textilis, B. tulda, $B$. tuldoides, $B$. ventricosa, $B$. vulgaris, $B$. vulgaris var. vittata and $B$. beecheyana, including Ochlandra travancorica) were gathered from clumps of 8-10 years old (collection of the Tatuí Experimental Station of the Instituto Agronômico) (Azzini \& Ciaramello 1971, Ciaramello \& Azzini 1971a and 1971b). From the Dendrocalamus genus, the following species were selected: $D$. asper, D. giganteus and $D$. latiflorus from the aforementioned collection, as well as D. strictus collected at the Campinas Experimental Center (Ciaramello \& Azzini 1971c). Finally, from the Guadua genus, the selected species were G. amplexifolia, G. angustifolia, G. longifolia (as G. spinosa) and G. superba (from both places as above) (Azzini et al. 1977). Measurements carried out by Guimarães Junior et al. (2010) for Bambusa vulgaris were also considered, with bamboo samples from the largest Brazilian commercial plantation (Pernambuco state), focused on pulp and paper production. Similarly, for Dendrocalamus, the average values of two sources of Dendrocalamus asper were taken into account (two experimental areas of the Universidade de Brasília, Federal District, Brazil) (Prates 2013).

Fiber dimensions are variables influencing diverse physical, mechanical and structural characteristic properties of products created with the material (e.g. panels and/or cellulose and paper). The average values of the fiber dimensions were used to calculate the following indexes and coefficients (Nisgoski et al. 2012): i) aspect ratio or inflection index $-\mathrm{ARI}=\mathrm{Fl} / \mathrm{Fw}$; ii) flexibility coefficient $-\mathrm{FC}=$ $\mathrm{Ld} / \mathrm{Fw}$; iii) wall fraction $-\mathrm{WF}=100 \times(2 \times \mathrm{Wt}) / \mathrm{Fw}$; iv) Runkel index - RI $=(2 \times \mathrm{Wt}) / \mathrm{Ld}$; where: $\mathrm{Fl}$ is the fiber length $(\mathrm{mm})$; Fw the fiber width $(\mu \mathrm{m})$; Ld the lumen diameter $(\mu \mathrm{m})$; and $\mathrm{Wt}$ the wall thickness $(\mu \mathrm{m})$.

The aspect or fiber slenderness ratio, also called felting or inflection index, is directly related to the material strength (usually relative to the paper resistance to tearing). In short, when the fibers are long and thin, there are greater numbers of connections, allowing for resistant straps.

The flexibility coefficient is related to the degree of collapse that the fibers undergo during their transformation process into product. If it is intense, it results in a less tensile strength and greater tendency to rupture. In general, short fibers generate more areas of bonds and crosses per available mass unit. Thus, if the fiber is flexible, this coefficient is higher, hence increasing the resistance to the burst due to the greater number of connections among them (Nisgoski et al. 2012).

The wall fraction, because it describes the ratio of the total wall thickness to the total fiber width, indicates its rigidity. In the case of a very high index, the fiber is "rigid and not flexible", making it difficult to interconnect "ffiber with fiber" and interfering with the material resistance (Nisgoski et al. 2012).

The Runkel index indicates flexibility and assesses the degree of fiber collapse during its product transformation process. If it is reduced, it will allow a greater bonding of the contact surface (union) among the fibers, increasing the resistance of the material to traction and bursting (Florsheim et al. 2009).

Anatomical elements of bamboo stems are all longitude-oriented, occurring only growth in length, with incredible speed. However, they present variations in the characteristics of the fibers (structural function) among the different species, what results in different mechanical resistances and allows varied uses (Azzini \& Salgado 1982). The average values for the volume determination in commercial material estimated from the stalks and their respective basic densities are shown in Table 1, while the micrometric analysis of the fiber dimensions (length, width, wall thickness and lumen diameter) are presented in Table 2.

The genus with the longest length, diameter and biomass weight was Dendrocalamus. It was found that this genus had below-average density values, especially $D$. asper $\left(0.599 \mathrm{~g} \mathrm{~cm}^{-3}\right)$ and D. giganteus $\left(0.552 \mathrm{~g} \mathrm{~cm}^{-3}\right)$. Similarly, Guadua presented below-average values for $G$. angustifolia $\left(0.451 \mathrm{~g} \mathrm{~cm}^{-3}\right)$, G. spinosa $\left(0.489 \mathrm{~g} \mathrm{~cm}^{-3}\right)$ and G. superba $\left(0.559 \mathrm{~g} \mathrm{~cm}^{-3}\right)$. In contrast, the genus with the highest average density was Bambusa $\left(0.685 \mathrm{~g} \mathrm{~cm}^{-3}\right)$, ranging from $0.608 \mathrm{~g} \mathrm{~cm}^{-3}$ to $0.780 \mathrm{~g} \mathrm{~cm}^{-3}$, being $B$. dissimulator the highest density species. On the other hand, the values for basic density ranged from $0.451 \mathrm{~g} \mathrm{~cm}^{-3}$ to $0.654 \mathrm{~g} \mathrm{~cm}^{-3}$ for Guadua and from $0.552 \mathrm{~g} \mathrm{~cm}^{-3}$ to $0.683 \mathrm{~g} \mathrm{~cm}^{-3}$ for Dendrocalamus. Thus, the total bulk density ranged from $0.451 \mathrm{~g} \mathrm{~cm}^{-3}$ for $G$. angustifolia to $0.780 \mathrm{~g} \mathrm{~cm}^{-3}$ for $B$. dissimulator.

The basic density is directly influenced by the cell wall thickness of the fibers, which interferes in the final resistance of the generated product. Species with a lower basic density have fibers with thinner 
walls that flatten during the production process of different products (paper, panel, etc.), resulting in a greater adhesion among the fibers. In general, this scenario is significant among bamboo species, due to the wide diversity of perceived density values.

Variations in the mean density values of the stems were also found for the same species. This fact is related to the soil-climatic conditions, i.e., high/ less soil nutrient availability, temperature variations, climate type and local topographic conditions.

The classification of the International Association of Wood Anatomists splits fibers into three groups: medium-length $(0.91-1.60 \mathrm{~mm})$, moderately long (1.61-2.20 mm) and very long (2.21-3.00 mm) (IAWA 1989, Adia et al. 2014). Among the studied species, the mean fiber length ranged from $1.65 \mathrm{~mm}$ for $G$. spinosa to $3.63 \mathrm{~mm}$ for $D$. asper, with an overall mean of $2.29 \mathrm{~mm}$. Thus, in a general context, the analyzed species can be classified as owing very long fibers. B. vulgaris, D. asper, $D$. giganteus and B. vulgaris var. vittata presented the highest values, all of them with more than $3 \mathrm{~mm}$ in length. In turn, G. spinosa and G. amplexifolia have fibers shorter than $1.7 \mathrm{~mm}$ in length, i.e., closer to the dimensions of angiosperm fibers, commonly classified as "short fibers".

The mean fiber width ranged from $14.22 \mu \mathrm{m}$ for $G$. superba to $19.97 \mu \mathrm{m}$ for $B$. nutans, with an overall mean of $16.4 \mu \mathrm{m}$. B. nutans and D. giganteus are those with values above $19.09 \mu \mathrm{m}$, whereas $G$. superba, B. molingensis, G. spinosa, G. amplexifolia and $B$. ventricosa had a width of less than $14.8 \mu \mathrm{m}$.

$B$. tulda, B. tuldoides and B. nutans are the ones with the highest average wall thickness, with values higher than $7.09 \mu \mathrm{m}$, which are much higher than the diameter of their respective lumens. In turn, $B$. ventricosa and $B$. vulgaris present the lowest average thickness.

The largest lumens were found for $D$. asper and $D$. giganteus, which were greater than $5 \mathrm{~mm}$, i.e., similar to their wall thickness. On the other hand, values lower than $3 \mathrm{~mm}$ were found for B. stinostachya, B. nutans, B. tulda, G. superba and $G$. angustifolia. However, all values obtained represent diameters classified as narrow, which increase the strength of the product to tearing.

According to the data of this study, bamboo fibers have a length well beyond their width (wall

Table 1. Stem morphological characteristics ${ }^{1,2}$ of commercial bamboo species with occurrence in Brazil.

\begin{tabular}{|c|c|c|c|c|c|c|c|c|}
\hline Species & $\begin{array}{l}\text { SL } \\
(\mathrm{m})\end{array}$ & $\begin{array}{l}\text { DBH } \\
(\mathrm{cm})\end{array}$ & $\begin{array}{c}\mathrm{IL} \\
(\mathrm{cm})\end{array}$ & $\begin{array}{c}\mathrm{NI} \\
\text { (unit) }\end{array}$ & $\begin{array}{l}\text { SW } \\
(\mathrm{kg})\end{array}$ & $\begin{array}{l}\text { DW } \\
(\mathrm{kg})\end{array}$ & $\begin{array}{c}\mathrm{BD} \\
\left(\mathrm{g} \mathrm{cm}^{-3}\right)\end{array}$ & Reference \\
\hline Bambusa beecheyana & 8.97 & 7.80 & 28 & 32 & - & 10.50 & 0.670 & Ciamello \& Azzini (1971a) \\
\hline B. dissimulator & 9.52 & 4.58 & 41 & 23 & - & 5.19 & 0.780 & \multirow{2}{*}{ Azzini \& Ciamello (1971) } \\
\hline B. malingensis & 7.36 & 4.33 & 28 & 26 & - & 3.49 & 0.700 & \\
\hline B. nutans & 9.95 & 5.83 & 38 & 26 & - & 7.75 & 0.615 & Ciamello \& Azzini (1971a) \\
\hline B. oldhamii & 9.93 & 6.94 & 41 & 24 & - & 8.37 & 0.608 & Azzini \& Salgado (1982) \\
\hline B. stenostachya & 15.10 & 8.17 & 35 & 43 & - & 17.50 & 0.653 & Ciamello \& Azzini (1971a) \\
\hline B. textilis & 8.13 & 4.77 & 44 & 18 & - & 3.80 & 0.690 & Azzini \& Ciamello (1971) \\
\hline B. tulda & 11.90 & 6.56 & 49 & 24 & - & 11.89 & 0.773 & Ciamello \& Azzini (1971a) \\
\hline B. tuldoides & 9.15 & 4.26 & 46 & 19 & - & 3.75 & 0.620 & \multirow{2}{*}{ Azzini \& Ciamello (1971) } \\
\hline B. ventricosa & 9.30 & 4.84 & 44 & 21 & - & 4.47 & 0.640 & \\
\hline B. vulgaris & 10.70 & 8.06 & 32 & 33 & - & 12.45 & 0.747 & \multirow{2}{*}{ Ciamello \& Azzini (1971c) } \\
\hline B. vulgaris var. vittata & 9.30 & 7.22 & 34 & 27 & - & 10.27 & 0.730 & \\
\hline Dendrocalamus asper* & 25.60 & 15.40 & 46 & 62 & - & - & - & Prates (2013) \\
\hline D. asper & 14.50 & 12.20 & 34 & 43 & 61.25 & 36.93 & 0.599 & \multirow{4}{*}{ Ciamello \& Azzini (1971b) } \\
\hline D. giganteus & 16.00 & 14.20 & 34 & 47 & 84.50 & 40.73 & 0.552 & \\
\hline D. latiflorus & 11.50 & 11.50 & 37 & 31 & 40.65 & 21.58 & 0.683 & \\
\hline D. strictus & 10.00 & 7.60 & 38 & 26 & 15.00 & 8.94 & 0.667 & \\
\hline Guadua amplexifolia & - & - & - & - & - & - & 0.654 & \multirow{4}{*}{ Azzini et al. (1977) } \\
\hline G. angustifolia & - & - & - & - & - & - & 0.451 & \\
\hline G. spinosa & - & - & - & - & - & - & 0.489 & \\
\hline G. superba & - & - & - & - & - & - & 0.559 & \\
\hline Ochlandra travancorica & 11.30 & 9.40 & 40 & - & - & 26.00 & 0.704 & Salgado et al. (1994) \\
\hline
\end{tabular}


Table 2. Fibers dimensions ${ }^{1}$ of bamboo species with occurrence in Brazil.

\begin{tabular}{|c|c|c|c|c|c|c|c|c|c|}
\hline \multirow{2}{*}{ Species } & \multicolumn{3}{|c|}{ — Length $(\mathrm{mm})$} & \multicolumn{3}{|c|}{ — Width $(\mu \mathrm{m})$} & \multirow{2}{*}{$\begin{array}{c}\mathrm{Ld} \\
(\mu \mathrm{m})\end{array}$} & \multirow{2}{*}{$\begin{array}{c}\mathrm{Wt} \\
(\mu \mathrm{m})\end{array}$} & \multirow{2}{*}{ Reference } \\
\hline & Max & Med & Min & Max & Med & Min & & & \\
\hline Bambusa beecheyana & 3.50 & 1.93 & 1.06 & 29.22 & 17.20 & 7.44 & 3.55 & 6.82 & Ciamello \& Azzini (1971a) \\
\hline B. dissimulator & 4.12 & 2.32 & 1.20 & 31.13 & 15.19 & 8.16 & 3.38 & 5.91 & \multirow{2}{*}{ Azzini \& Ciamello (1971) } \\
\hline B. malingensis & 3.71 & 2.07 & 1.10 & 27.84 & 14.79 & 7.79 & 3.45 & 6.67 & \\
\hline B. nutans & 4.13 & 2.29 & 1.37 & 30.43 & 19.97 & 8.80 & 2.77 & 7.10 & Ciamello \& Azzini (1971a) \\
\hline B. oldhamii & 3.63 & 1.92 & 0.98 & 34.66 & 16.97 & 8.52 & 3.17 & 6.90 & Azzini \& Salgado (1982) \\
\hline B. stenostachya & 3.71 & 2.22 & 1.06 & 27.06 & 15.49 & 6.65 & 2.90 & 6.29 & Ciamello \& Azzini (1971a) \\
\hline B. textilis & 3.41 & 2.04 & 1.04 & 28.21 & 16.78 & 8.17 & 3.02 & 6.88 & Azzini \& Ciamello (1971) \\
\hline B. tulda & 3.79 & 2.15 & 1.80 & 33.68 & 17.33 & 7.73 & 2.34 & 7.50 & Ciamello \& Azzini (1971a) \\
\hline B. tuldoides & 3.72 & 1.89 & 1.00 & 29.25 & 18.21 & 9.31 & 3.83 & 7.19 & Azzini \& Ciamello (1971) \\
\hline B. ventricosa & 3.49 & 1.90 & 1.06 & 26.42 & 14.38 & 5.15 & 3.31 & 5.54 & Azzini \& Ciamello (1971) \\
\hline B. vulgaris & 3.44 & 2.30 & 1.43 & 24.96 & 13.93 & 10.36 & 3.81 & 5.06 & Guimarães Junior et al. (2010) \\
\hline B. vulgaris & 6.18 & 3.43 & 1.49 & 32.21 & 15.41 & 7.46 & 3.73 & 5.84 & \multirow{2}{*}{ Ciamello \& Azzini (1971c) } \\
\hline B. vulgaris var. vittata & 5.46 & 2.98 & 1.41 & 29.21 & 16.21 & 7.96 & 3.43 & 6.39 & \\
\hline Dendrocalamus asper* & 6.82 & 3.63 & 1.64 & 33.27 & 17.04 & 7.14 & 5.66 & 5.69 & Prates (2013) \\
\hline D. asper & 4.52 & 2.43 & 1.10 & 31.71 & 17.89 & 9.58 & 3.97 & 6.96 & \multirow{4}{*}{ Ciamello \& Azzini (1971b) } \\
\hline D. giganteus & 5.46 & 3.08 & 1.57 & 31.06 & 19.10 & 10.87 & 5.66 & 6.72 & \\
\hline D. latiflorus & 4.08 & 2.44 & 1.35 & 30.43 & 17.06 & 9.88 & 3.44 & 6.81 & \\
\hline D. strictus & 3.56 & 2.22 & 1.30 & 34.21 & 18.17 & 7.01 & 4.33 & 6.92 & \\
\hline Guadua amplexifolia & 3.30 & 1.69 & 0.64 & 30.43 & 14.47 & 5.72 & 3.28 & 5.55 & \multirow{4}{*}{ Azzini et al. (1977) } \\
\hline G. angustifolia & 4.14 & 1.93 & 0.56 & 29.71 & 16.04 & 7.30 & 2.12 & 6.96 & \\
\hline G. spinosa & 3.22 & 1.65 & 0.53 & 30.21 & 14.57 & 7.23 & 3.10 & 5.74 & \\
\hline G. superba & 4.14 & 1.94 & 0.42 & 25.05 & 14.22 & 6.37 & 2.14 & 6.04 & \\
\hline Ochlandra travancorica & - & 2.20 & - & - & 16.70 & - & 4.91 & 6.00 & Azzini \& Salgado (1982) \\
\hline
\end{tabular}

${ }^{1}$ Max, Med and Min: maximum, median and minimum values, respectively; Ld: lumen diameter; Wt: wall thickness. * Mean values from two sources.

thickness + lumen diameter). This fact is relevant, because there is a correlation between these fiber dimensions and the physical-mechanical properties of the resulting product.

Table 3 shows the chemical composition of different bamboo species, considering the average contents of Carbon (C), Hydrogen $(\mathrm{H})$, Nitrogen $(\mathrm{N})$ and Oxygen $(\mathrm{O})$, as well as the $\mathrm{O} / \mathrm{C}$ ratio as biomass in several production processes.

Bamboo is considered a composite material, naturally formed of lignin, cellulose and hemicellulose. Its structure consists of relatively long and aligned cellulose fibers, which act as reinforcement, embedded in a matrix of hemicellulose and lignin, whose structure is constituted by $50 \%$ of parenchyma cells, $40 \%$ of fiber bundles and $10 \%$ of vascular bundles (Azzini \& Salgado 1982, Chaowana et al. 2015, Rusch et al. 2018). The main chemical components found in the inner bamboo stem are cellulose, hemicellulose and lignin, which represent more than $90 \%$ of the total biomass. The content of cellulose in bamboo ranges from $40 \%$ to $60 \%$, not being much different from traditional wood, with $40 \%$ to $52 \%$ in conifers and $38 \%$ to $56 \%$ in angiosperms (Liese \& Tang 2015, Nayak \& Mishra 2016).

Table 3. Biomass chemical composition of commercial bamboo species with occurrence in Brazil.

\begin{tabular}{lcccccl}
\hline \multicolumn{1}{c}{ Biomass } & $\mathrm{C}$ & $\mathrm{H}$ & $\mathrm{N}$ & $\mathrm{O}$ & $\mathrm{O} / \mathrm{C}$ & \multicolumn{1}{c}{ Reference } \\
\hline Bambusa vulgaris & 49.60 & 6.10 & 0.40 & 44.00 & 0.89 & Macêdo et al. (2014) \\
\hline B. vulgaris & 46.80 & 6.38 & 0.22 & 46.60 & 0.99 & Rousset et al. (2011) \\
\hline Dendrocalamus giganteus & 44.26 & 5.48 & 0.46 & 42.66 & 0.96 & Hernández-Mena et al. (2014) \\
\hline D. latiflorus & 44.22 & 6.10 & 0.07 & 45.63 & 1.03 & \\
Phyllostachys makinoi & 43.90 & 6.06 & 0.06 & 41.47 & 0.94 & Lin et al. (2016) \\
P. pubescens & 45.25 & 5.71 & 0.08 & 43.89 & 0.97 & \\
\hline
\end{tabular}


Bamboo species present holocellulose content (cellulose + hemicellulose) ranging from $60 \%$ to $70 \%$ and lignin from $20 \%$ to $30 \%$, and this composition may change according to the species, growth conditions, age and part of the stem (Liese 1992). On the other hand, secondary chemical constituents (waxes, resins, tannins, proteins and soluble ashes) are present in small amounts (Vena et al. 2013, Chaowana 2013, Liese \& Tang 2015, Nayak \& Mishra 2016). Due to these levels, bamboo becomes a suitable raw material for various industrial activities.

\section{CORRELATION BETWEEN FIBER DIMENSIONS AND PHYSICAL-MECHANICAL PROPERTIES}

Data of the analyzed bamboo species showed variations in both the fiber length and width. These variations interfere with the values for wall fraction, flexibility coefficient, and felting and Runkel indices (Table 4), which establish the behavior and resistance of a given fiber. Thus, the calculation of these parameters helps to predict the results when employing a fiber for a certain use, due to the influence of their dimensions, density, volume, tensile strength and compression.

The wall fraction ranged from $66.78 \%$ to values near $90.20 \%$, with $D$. asper showing the lowest percentage, because its lumen diameter is greater than its wall thickness. In turn, the larger wall fraction percentages of $B$. malingensis are due to its considerable wall thickness, if compared to the total fiber width, and G. angustifolia $(86.78 \%)$, B. tulda $(86.56 \%)$ and G. superba $(84.95 \%)$ due to the reduced average diameter of their lumen. Thus, the analyzed species were classified as having very thick walls, i.e., with high firmness. Another relevant aspect is the small reduction in fiber length with an increasing stem height (Liese 1980, Brito et al. 2015).

The aspect ratio index of the analyzed species can be classified as high, because all species showed values greater than 50 , suggesting a good strength by the fact that bamboo fibers are long and thin. The index ranged from 104 up to 222, resulting from significant variations in the mean fiber length and width of these different species. For composites and wood panels, this parameter is very important, because the larger

Table 4. Fiber coefficients ${ }^{1}$ of commercial bamboo species with occurrence in Brazil.

\begin{tabular}{|c|c|c|c|c|c|}
\hline Species & WF (\%) & $\mathrm{FC}(\%)$ & ARI & RI & Reference \\
\hline Bambusa beecheyana & 79.30 & 20.63 & 112 & 3.84 & Ciamello \& Azzini (1971a) \\
\hline B. dissimulator & 77.81 & 22.25 & 153 & 3.50 & \multirow{2}{*}{ Azzini \& Ciamello (1971) } \\
\hline B. malingensis & 90.20 & 23.32 & 140 & 3.87 & \\
\hline B. nutans & 71.11 & 16.32 & 135 & 5.13 & Ciamello \& Azzini (1971a) \\
\hline B. oldhamii & 81.32 & 18.68 & 113 & 4.35 & Azzini \& Salgado (1982) \\
\hline B. stenostachya & 81.21 & 18.71 & 144 & 4.34 & Ciamello \& Azzini (1971a) \\
\hline B. textilis & 82.00 & 18.00 & 122 & 4.56 & Azzini \& Ciamello (1971) \\
\hline B. tulda & 86.56 & 13.50 & 124 & 6.41 & Ciamello \& Azzini (1971a) \\
\hline B. tuldoides & 78.97 & 21.03 & 104 & 3.75 & \multirow{2}{*}{ Azzini \& Ciamello (1971) } \\
\hline B. ventricosa & 77.05 & 23.02 & 132 & 3.35 & \\
\hline B. vulgaris & 71.94 & 28.06 & 172 & 3.15 & Guimarães Junior et al. (2010) \\
\hline B. vulgaris & 75.79 & 24.20 & 222 & 3.13 & \multirow{2}{*}{ Ciamello \& Azzini (1971c) } \\
\hline B. vulgaris var. vittata & 78.84 & 21.16 & 184 & 3.73 & \\
\hline Dendrocalamus asper* & 66.78 & 33.21 & 213 & 2.01 & Prates (2013) \\
\hline D. asper & 77.81 & 22.19 & 136 & 3.51 & \multirow{4}{*}{ Ciamello \& Azzini (1971b) } \\
\hline D. giganteus & 70.37 & 29.63 & 161 & 2.37 & \\
\hline D. latiflorus & 79.84 & 20.16 & 143 & 3.96 & \\
\hline D. strictus & 76.17 & 23.83 & 122 & 3.20 & \\
\hline Guadua amplexifolia & 76.71 & 22.67 & 117 & 3.38 & \multirow{4}{*}{ Azzini et al. (1977) } \\
\hline G. angustifolia & 86.78 & 13.21 & 120 & 6.57 & \\
\hline G. spinosa & 78.79 & 21.28 & 113 & 3.70 & \\
\hline G. superba & 84.95 & 15.05 & 136 & 5.64 & \\
\hline Ochlandra travancorica & 71.85 & 29.40 & 131 & 2.44 & Azzini \& Salgado (1982) \\
\hline
\end{tabular}

${ }^{1}$ WF: wall fraction (\%); FC: flexibility coefficient (\%); ARI: aspect ratio index; RI: Runkel index. * Mean values from two sources. 
the values the better the performance of the fibers as a reinforcement material. For Guimarães Junior et al. (2010), results of anatomical analysis and the relationships among the dimensions of bamboo fibers make them potential candidates to compete with flax, sisal and "curauá" fibers in the production of many products, particularly polymeric composites for the automotive, electronics, nautical, aerospace and packaging industry.

For Correia et al. (2015), bamboo fibers, wherever if in macro, micro and nano scales, have a superior strength and resistance, when compared to other commercial vegetable fibers, enabling them to be used as a reinforcement of organic and inorganic matrices, providing an increased mechanical strength.

On the other hand, the flexibility coefficient of these species, in a general context, is considered low (less than 35), especially for G. angustifolia (13.21) and B. tulda (13.50). This characteristic is due to the fact that their walls are very thick, if compared to a reduced lumen. Because of the high thickness, the fibers do not collapse, what results in a small contact surface, i.e., a reduced fiber-fiber bonding. The species with the best type of cell wall was $D$. asper (33.21), which has intermediate walls and large-diameter lumens, slightly increasing the fiber collapse and resulting in a greater fiber-fiber contact and union.

Finally, the Runkel index, ranging from 2.01 in D. asper to 6.57 in G. angustifolia, was found to be above the value considered advisable for raw materials to be used in the pulp and paper industry. According to Nisgoski et al. (2012), high values are not desirable, as fiber becomes rigid and with a greater difficulty of accommodation and union. For polymeric composites, the fibers do not need to bind together more than the value considered ideal for papermaking. Thus, even with higher values for bamboo, in comparison with the wood species used in the paper industry, the reinforcement properties are satisfactory, allowing their use as reinforcement in composites and nanocomposites.

The micrometric analysis of fibers is also correlated with the strength characteristics of the material. The length and diameter of the fibers, along with the thickness of their cell walls, correlate with the elasticity modulus and the compressive strength, although the diameter of the fiber is not influenced neither by its length nor by the thickness of its cell walls.

\section{CONCLUSIONS}

1. The basic density in the test stem-specimens of the surveyed bamboo genera differs and increases in the following order: Bambusa spp. > Dendrocalamus spp. > Guadua spp.;

2. The fibers of the surveyed bamboo species have an intermediate length, in relation to the main commercially cultivated tree species (Gymnospermas and Angiospermas). However, their dimensions vary according to the region of the stem wall, reducing from the peripheral zone towards the central zone. In general, the fibers tend to be $20 \%$ to $40 \%$ shorter in the inner zone of the stem wall. In the longitudinal direction, its maximum length occurs in the median range of the internode and decreases in the extremities;

3. Bamboo fibers are thin, with a narrow lumen, relatively thick cell walls and smaller length than the Gymnospermas fibers. Due to these characteristics, they present higher values for the wall-fraction index and lower for the coefficient of flexibility, thus conferring high values for strength, stiffness and resistance to collapse on processing, if compared to arboreal species;

4. The bamboo fibers in the surveyed species can be considered light, rigid and strong. Such characteristics give them a high firmness, thus positively influencing the physical-mechanical resistance of materials produced with bamboo.

\section{REFERENCES}

ADIA, D. S. et al. Exploration of unutilized fast growing wood species from secondary forest in central Kalimantan: study on the fiber characteristic and wood density. Procedia Environmental Sciences, v. 20, n. 1, p. 321327, 2014.

AZZINI, A.; CIARAMELLO, D. Bambu como matériaprima para papel: IV. Estudos sobre o emprego de cinco espécies de Bambusa, na produção de celulose sulfato. Bragantia, v. 30, n. 23, p. 305-319, 1971.

AZZINI, A. et al. Densidade básica e dimensões das fibras em bambus do gênero Guadua. Bragantia, v. 36, n. 1, p. I-V, 1977.

AZZINI, A.; SALGADO, A. Bambu e suas possibilidades industriais. In: CONGRESSO ANUAL DAASSOCIAÇÃO BRASILEIRA DE CELULOSE E PAPEL, 15., 1982, São Paulo. Anais... São Paulo: ABCP, 1982. p. 205-224. 
BRITO, F. M. S. et al. Caracterização anatômica e física do bambu gigante (Dendrocalamus giganteus Munro). Floresta e Ambiente, v. 22, n. 4, p. 559-566, 2015.

CHAOWANA, P. Bamboo: an alternative raw material for wood and wood-based composites. Journal of Materials Science Research, v. 2, n. 2, p. 90-102, 2013.

CHAOWANA, P.; BARBU, M. C.; FROHWALD, A. Bamboo: a functionally graded composite material. Forest Products Journal, v. 65, n. 3-4, p. 48-53, 2015.

CIARAMELLO, D.; AZZINI, A. Bambu como matériaprima para papel: estudos sobre o emprego de Bambusa vulgaris Schrad, Bambusa vulgaris Schrad var. vittata A \& C Riv. e Bambusa oldhami Munro, na produção de celulose sulfato. O Papel, v. 32, n. 2, p. 33-40, 1971 b.

CIARAMELLO, D.; AZZINI, A. Bambu como matériaprima para papel: III. Estudos sobre o emprego de quatro espécies de Bambusa, na produção de celulose sulfato. Bragantia, v. 30, n. 19, p. 199-213, 1971a.

CIARAMELLO, D.; AZZINI, A. Bambu como matériaprima para papel: V. Estudos sobre o emprego de quatro espécies de Dendrocalamus, na produção de celulose sulfato. Bragantia, v. 30, n. 24, p. 321-336, 1971c.

CORREIA, V. C. et al. Macro, micro and nanoscale bamboo fiber as a potential reinforcement for composites. Key Engineering Materials, v. 668, n. 1, p. 11-16, 2015.

DIAS JÚNIOR, A. F. et al. Caracterização de briquetes produzidos com resíduos agroflorestais. Pesquisa Florestal Brasileira, v. 34, n. 79, p. 225-234, 2014.

FILGUEIRAS, T. S. et al. Poaceae: lista de espécies da flora do Brasil. Rio de Janeiro: Jardim Botânico, 2013.

FILGUEIRAS, T. S.; GONÇALVES, A. P. S. A checklist of the basal grasses and bamboos in Brazil (Poaceae). Bamboo Science \& Culture, v. 18, n. 1, p. 7-18, 2004.

FLORSHEIM, S. M. B. et al. Variação nas dimensões dos elementos anatômicos da madeira de Eucalyptus dunii aos sete anos de idade. Revista do Instituto Florestal, v. 21, n. 1, p. 79-91, 2009.

GRECO, T. M. et al. Diversity of bamboo in Brazil. Journal of Tropical and Subtropical Botany, v. 23, n. 1, p. 1-16, 2015.

GRECO, T. M.; CROMBERG, M. Bambu: cultivo e manejo. Florianópolis: Insular, 2011.

GUIMARÃES JUNIOR, M. et al. Caracterização anatômica da fibra de bambu (Bambusa vulgaris) visando sua utilização em compósitos poliméricos. Revista Iberoamericana de Polímeros, v. 11, n. 7, p. 442-456, 2010.

HERNÁNDEZ-MENA, L. et al. Slow pyrolysis of bamboo biomass: analysis of biochar properties. Chemical Engineering Transactions, v. 37, n. 1, p. 115-120, 2014.
INTERNATIONAL ASSOCIATION OF WOOD ANATOMISTS (IAWA). List of microscopic features for hardwood identification, with an appendix on nonanatomical information. IAWA Bulletin, v. 10, n. 3, p. 219$332,1989$.

KUTTIRAJA, M. et al. Bioethanol production from bamboo (Dendrocalamus sp.) process waste. Biomass and Bioenergy, v. 59, n. 1, p. 142-150, 2013.

LANNA, S. L. de B. et al. Eco-design: a eficiência de produtos feitos de bambu para o sequestro de carbono. Estudos em Design, v. 22, n. 1, p. 146-156, 2014.

LIESE, W. Anatomy of bamboo. In: LESSARD, G.; CHOUINARD, A. (Eds.). Bamboo research in Asia: proceedings of a workshop held in Singapore. Ottawa: IDRC, 1980. p. 161-164.

LIESE, W. The structure of bamboo in relation to its properties and utilization. In: INTERNATIONAL SYMPOSIUM ON INDUSTRIAL USE OF BAMBOO, 1., 1992, Beijing. Proceedings... Hamburg: Hamburg University, 1992. p. 96-100.

LIESE, W.; TANG, T. K. H. Properties of the bamboo culm. In: LIESE, W.; KOHL, M. (Eds.). Tropical forestry, bamboo: the plant and its uses. Hamburg: Springer, 2015. p. 227-256.

LIN, L. et al. Bamboo-derived fuel from Dendrocalamus latiflorus, Phyllostachys makinoi, and Phyllostachys pubescens waste. BioResources, v. 11, n. 4, p. 8425-8434, 2016.

LIU, X. et al. Engineered bamboo nomenclature. BioResources, v. 11, n. 1, p. 1141-1161, 2016.

MACÊDO, L. A. et al. Influência da composição da biomassa no rendimento em condensáveis da torrefação de resíduos vegetais. Pesquisa Florestal Brasileira, v. 34, n. 80, p. 417-424, 2014.

NAYAK, L.; MISHRA, S. P. Prospect of bamboo as a renewable textile fiber: historical overview, labeling, controversies and regulation. Fashion and Textiles, v. 3, n. 2, p. 1-23, 2016.

NEPAL. Department of Forest Research and Survey. Market development of bamboo and rattan products with potential project. Babarmahal: DFRS, 2011.

NISGOSKI, S. et al. Características anatômicas da madeira e índices de resistência do papel de Schizolobium parahyba (Vell.) Blake provenientes de plantio experimental. Scientia Forestalis, v. 40, n. 94, p. 203-211, 2012.

OSTAPIV, F. Resistência mecânica do material compósito: madeira de eucalipto-lâmina de bambu. 2011. 148 f. Tese (Doutorado em Engenharia Mecânica) - Universidade Estadual Paulista, Guaratinguetá, 2011. 
PEREIRA, M. A. dos R. Projeto bambu: introdução de espécies, manejo, caracterização e aplicações. Bauru: Ed. da Universidade de São Paulo, 2012.

PRATES, E. M. B. Morfologia externa e anatomia do colmo de Dendrocalamus asper (Poaceae: Bambusoideae) em duas localidades no Distrito Federal, Brasil. 2013. 84 f. Dissertação (Mestrado em Ciências Florestais) Universidade de Brasília, Brasília, DF, 2013.

ROUSSET, P. et al. Enhancing the combustible properties of bamboo by torrefaction. Bioresource Technology, v. 102, n. 17 , p. 8225-8231, 2011.

RUSCH, F. et al. Physical-mechanical properties of laminated bamboo panels. Pesquisa Agropecuária Tropical, v. 49, e53714, 2019.

RUSCH, F.; HILLIG, E.; CEOLIN, G. B. Anatomia de hastes adultas de bambu: uma revisão. Pesquisa Florestal Brasileira, v. 38, e201701530, 2018.

SALGADO, A. L. de B. et al. Instruções técnicas sobre o bambu. Campinas: Instituto Agronômico, 1994.
SILVEIRA, E. S. et al. Influência de espécies de bambu como alimento no crescimento populacional e na preferência alimentar do caruncho-do-bambu. In: DRUMOND, P. M.; WIEDMAN, G. (Orgs.). Bambus no Brasil: da biologia à tecnologia. Rio de Janeiro: $\mathrm{ICH}$, 2017. p. 130-144.

TRIPATHI, S. K. et al. Pulp and papermaking properties of bamboo species Melocanna baccifera. Cellulose Chemistry and Technology, v. 52, n. 1-2, p. 81-88, 2018.

VENA, P. F. et al. Hemicelluloses extraction from giant bamboo (Bambusa balcooa Roxburgh) prior to kraft or soda-AQ pulping and its effect on pulp physical properties. Holzforschung, v. 67, n. 8, p. 863-870, 2013.

VORONTSOVA, M. S. et al. World checklist of bamboos and rattans. Beijing: INBAR, 2017.

YEASMIN, L. et al. Bamboo: an overview on its genetic diversity and characterization. Biotech, v. 201, n. 5, p. 1-11, 2014. 